\title{
Ranking criteria for assessment of municipal solid waste dumping sites
}

\author{
Khalid Mahmood ${ }^{1 *}$, Syeda Adila Batool ${ }^{1}$, Muhammad Nawaz Chaudhary ${ }^{2}$, Zia Ul-Haq ${ }^{1}$ \\ ${ }^{1}$ Remote Sensing and GIS Group, Department of Space Science \\ University of the Punjab, Lahore, Pakistan \\ ${ }^{2}$ College of Earth and Environmental Sciences \\ University of the Punjab, Lahore, Pakistan \\ *Corresponding author's e-mail: khalid.m270@yahoo.com, khalid.spsc@pu.edu.pk
}

\begin{abstract}
Keywords: MSW dumping facility, hazard assessment, ranking criteria, Geographic Information System, remote sensing.
\end{abstract}

\begin{abstract}
Priority wise channelization of resources is the key to successful environmental management, especially when funds are limited. The study in hand has successfully developed an algorithmic criterion to compare hazardous effects of Municipal Solid Waste (MSW) dumping sites quantitatively. It is a Multi Criteria Analysis (MCA) that has made use of the scaling function to normalize the data values, Analytical Hierarchy Process (AHP) for assigning weights to input parameters showing their relevant importance, and Weighted Linear Combination (WLC) for aggregating the normalized scores. Input parameters have been divided into three classes namely Resident's Concerns, Groundwater Vulnerability and Surface Facilities. Remote Sensing data and GIS analysis were used to prepare most of the input data. To elaborate the idea, four dumpsites have been chosen as case study, namely Old-FSD, New-FSD, Saggian and Mahmood Booti. The comparison has been made first at class levels and then class scores have been aggregated into environmental normalized index for environmental impact ranking. The hierarchy of goodness found for the selected sites is New-FSD $>$ Old-FSD $>$ Mahmood Booti $>$ Saggian with comparative scores of goodness to environment as 36.67, 28.43, 21.26 and 13.63 respectively. Flexibility of proposed model to adjust any number of classes and parameters in one class will be very helpful for developing world where availability of data is the biggest hurdle in research based environmental sustainability planning. The model can be run even without purchasing satellite data and GIS software, with little inaccuracy, using imagery and measurement tools provided by Google Earth.
\end{abstract}

\section{Introduction}

Management of the Municipal Solid Waste (MSW) is as obvious as its generation through human activities. The management solutions place landfilling at the bottom of the hierarchy that includes many other options like recycling, incineration and source reduction. MSW management has become a challenging task for authorities due to decrease in availability of land for waste disposal and increasing awareness of health risks associated with mishandling of MSW (Liu et al. 2014). In developing world urbanization, poor planning, and unavailability of adequate resources add hurdles in sustainable MSW management. As a result, the existing facilities use unsanitary landfilling and open dumping practices, while collection and transportation is inadequate and outdated to support current scenario and requirements (Gorsevski et al. 2012, Ali et al. 2014). Hot climatic conditions are reported to intensify environmental hazards, with significant local as well as global dimensions, when get coupled with poor management systems (Sumathi et al. 2008, Liu et al. 2014).
Landfilling for the disposal of waste is the most popular and cheapest of all the waste management solutions (Biswas et al. 2010, Zhang et al. 2011). An acceptable landfill selection process requires extensive criteria and evaluation steps to optimize best available locations, eliminating subsequent nuisances (i.e., dust, odor and visual intrusion) and severe long term impacts (groundwater contamination) (Gorsevski et al. 2012). In general government policies regarding society, environmental protection level and economical budgeting are the factors, usually, considered for selecting a site of the waste disposal (Babalola and Basu 2011). Selecting a suitable MSW dumping location is a Multi Criterion Analysis (MCA) that uses many parameters including geology, underground aquifer, surface facilities, and resident's repulsion etc. (Zeinhom et al. 2010, Mahini and Gholamafard 2006, Al-jarrah et al. 2006, Babalola and Basu 2011, Liu et al. 2014, Eiselt and Marianov 2015). Even after selecting a suitable site using MCA, it still needs to be properly engineered, provided with a hydrological barrier and a closure cover. It is the closure cover due to which they got the name 'Landfill'. 
Due to shortage of finance, developing countries are facing a bigger problem of open dumping, there are no hydrological barriers, and no closure cover activity (Gorsevski et al. 2012, Ali et al. 2014). These un-engineered constructions with deficient standards and inadequate specifications are alarming to human health and environment (Hazra and Goel 2009, Li et al. 2012, Gorsevski et al. 2012). Exposure to rain and microbial activities made open dumps to pollute all forms of environment, the atmosphere (odor and spread of diseases), the lithosphere (soil degradation) and the hydrosphere (contamination of ground as well as surface water) (Marzougui and Mammou 2006, Demitriou et al. 2008, Singh et al. 2009, Li et al. 2012, Liu et al. 2014). Careless selection of location for these dumps without following any MCA adds up to their design deficiency.

With the increasing public awareness of environmental protection, neighboring open dumps to residential area have become a liability and their use is no more feasible (Eiselt and Marianov 2015). Addressing concerns of public health, many countries have already taken control measures against such dumps (Singh et al. 2009). The rest of the developing world, sooner or later, will have to take control of these health hazards. Sustainable development of the environment requires identification and assessment of the hazards associated with these dumps (Butt et al. 2008, Hazra and Goel 2009, Ali et al. 2014). In this regard, a decision-making tool that prioritizes existing open dumps on the basis of the hazard severity can be very helpful for better utilization of limited resources. Risk assessment of the existing dumping site is a starting step towards remedial measures of related hazards in all over the world (Butt et al. 2008). In general, the task of a decision-making system is to get an optimal solution from input information using an inference procedure. The inference procedure may be a mathematical model or an expert's advice. In the case of priority wise channelization of resources, it is highly needed to make the comparison quantitative, which is only possible through mathematical approach. Another advantage of mathematical models, that once they are formulated they need very little information from the decision makers, is making decision process easy (Eiselt and Marianov 2015). Such mathematical MCA usually includes either the Boolean approach, non-compensatory aggregation, or the Weighted Linear Combination (WLC) which uses compensatory aggregation rules, such that the favorable criteria outweigh the unfavorable one. WLC is much more flexible than the Boolean combination and provides full tradeoff among the used criteria.

Fuzzy set theory is recommended in the reviewed literature for providing scaling function as criteria of standardization, before the variables get coupled through WLC (Zadeh 1965, 1978, Jiang and Eastman 2000, Gorsevski et al. 2012, Liu et al. 2014). Standardization is the process of rescaling the criteria values so that they become mutually comparable without any conflict of units and significance of value number. In contrast to Boolean logic, the Fuzzy logic includes 'Yes' or 'No' as extreme cases of truth and includes various states of truth, for example a comparison between two things could be not tall or short but " 0.45 of tallness".

This research intends to develop algorithmic criteria to assess existing dumping sites. Geographic Information System (GIS) has been used in the study for different analysis as it provides an easy approach to evaluate the outcomes of various management alternatives (Rahman 2008, Almasri 2008, Eiselt and Marianov 2015). The overlay function of GIS allows decision makers to check violation of distance base prerequisites of a MSW dumping facility (Eiselt and Marianov 2015). The basic criteria used for the study is the same as used by a number of studies for pre assessment/optimization of landfills, but here the same parameters have been used for the post assessment.

\section{Materials and methods}

\section{Description of study area}

This study has mainly been done for Faisalabad, which is the second largest industrial city of Pakistan. With an area of about $1,496 \mathrm{~km}^{2}$ and an approximate population of 2.86 million it lies between longitudes $72.8^{\circ} \mathrm{E}$ to $73.3^{\circ} \mathrm{E}$ and latitudes $31.15^{\circ} \mathrm{N}$ to $31.63^{\circ} \mathrm{N}$ and an average altitude of 186 $\mathrm{m}$ above MSL. The climate of Faisalabad is hot and semi-arid with an average rainfall $480 \mathrm{~mm}$ per year, peak of rainfall is in the months of July and August with an average of about $200 \mathrm{~mm}$. On average the maximum temperature found in summer (May to September) is $37.8^{\circ} \mathrm{C}$ with peak in June $\left(40.7^{\circ} \mathrm{C}\right)$ and average of the minimum temperature found in winter (November to March) is $8^{\circ} \mathrm{C}$ with lowest in January $\left(4.4^{\circ} \mathrm{C}\right)$. Being an industrial hub, the city of Faisalabad has about 3,000 small, medium and large industrial units mostly dealing with the textile industry.

To elaborate the working of developed criteria for comparing dumping sites the city of Lahore has also been included in this study. Lahore lies between longitudes $74.012^{\circ} \mathrm{E}$ to $74.641^{\circ} \mathrm{E}$ and between latitudes $31.24^{\circ} \mathrm{N}$ to $31.751^{\circ} \mathrm{N}$ with an average elevation of $210 \mathrm{~m}$ above MSL. With an area of $1,772 \mathrm{Km}^{2}$ (District Census Report of Lahore 1998) Lahore is the second largest city in Pakistan and provincial capital of Punjab (Alam et al. 2012). Lahore with a population of approximately 10 million is bounded by the river Ravi on the north and west, on the east by Indian district of Amritsar and on the south by the Kasur district. The climate in Lahore is hot and semi-arid with an average rainfall of $680 \mathrm{~mm}$ per year. Average of the maximum temperature of Lahore found in summer (May to September) is $37.2^{\circ} \mathrm{C}$ with peak in June $\left(40.4^{\circ} \mathrm{C}\right)$ and average of the minimum temperature found in winter (November to March) is $9.44^{\circ} \mathrm{C}$ with lowest in January $\left(5.9^{\circ} \mathrm{C}\right)$.

Both Faisalabad and Lahore, like rest of Punjab do not possess a single scientifically managed waste disposal site. MSW is disposed off at waste disposal sites in a crude and primitive way. This practice creates complex and serious environmental problems, and grave consequences to public health. The open dumping is carried out mostly in the old ponds, depressions and excavations. Major dumps of both the cities have been chosen for this comparison, two from each city.

1. Old-FSD is the first government owned dumping facility in Faisalabad, lying at $31.386^{\circ} \mathrm{N}$ and $73.242^{\circ} \mathrm{E}$, where MSW dumping was started in 2003.

2. New-FSD is the new dumping facility in Faisalabad, lying at $31.398^{\circ} \mathrm{N}$ and $73.252^{\circ} \mathrm{E}$. At this location dumping was started in 2011, but for future, it is a proposed location for constructing a properly engineered landfill.

3. Saggian dumping site lies at $31.569^{\circ} \mathrm{N}$ and $74.268^{\circ} \mathrm{E}$, at northwestern edge of Lahore, in the flood plain of the river Ravi 
where dumping of waste started in 1995 and was abandoned in 2010 (Mahmood et al. 2015a).

4. Mahmood Booti is the government owned dumping facility, lying at $31.610^{\circ} \mathrm{N}$ and $74.385^{\circ} \mathrm{E}$, in northern outskirt of Lahore, it is in use for dumping of MSW since 1997 (Mahmood et al. 2015a).

\section{Methodology}

This study is intended to develop a comparative algorithm that can rank existing MSW dumping facilities. Selection of the criterion elements is, somehow, a controversial issue that depends on many factors, but a proposed model should have flexibility to incorporate any change in the input parameters as per local policy and availability of data. The input parameters for this study has been selected as per international practices and standards found in the reviewed literature (Zeinhom et al. 2010, Mahini and Gholamafard 2006, Al-jarrah et al. 2006, Babalola and Basu 2011, Liu et al. 2014, Eiselt and Marianov 2015). To discuss each of the major sector the chosen parameters have been divided into the following three categories.

\section{Resident's concerns ( $R$ )}

A dumping site either engineered (Landfill) or non-engineered (Open dump) must be located far from a residential area because of the political repulsion to its construction near populated regions under the principle of NIMBY (Not In My BackYard) (Babalola and Basu 2011) and NIABY (Not In Anyone's BackYard) (Gbanie et al. 2013, Eiselt and Marianov 2015). Therefore, the location of the dumping facility is very important to ensure sustainability of environment and to reduce the stigma related to human living in its vicinity (Liu et al. 2014). Resident's concerns are not limited to visual aesthetics only and also include effects of toxic gases and odor problems associated with MSW dumping (Gbanie et al. 2013). Different studies have used different distance criteria between residential area and MSW dumping facility. For example, Mahini and Gholamafard, 2006 have taken this distance as 1,000 meter. According to Babalola and Basu, 2011 this distance may be as low as 500 meters, whereas Adeli and Khorshiddoust, 2011 have suggested it to be at least 4,000 to 5,000 meters. The concern of residents have been parametrized into five variables: (R1) distance of the dumping side from the nearest residential colony (the greater the distance, the lower the hazardous effect will be), (R2) area of residence within 1,000 $\mathrm{m}$ of the dumping site $(1,000 \mathrm{~m}$ buffer around the facility is prohibited for human living as mentioned by most of the studies), (R3) number of houses in the 1,000 m buffer (as a house represents a family living in danger), (R4) number of people living in the $1,000 \mathrm{~m}$ buffer (members per family may vary location to location) and (R5) percentage of the days in a year when wind blows from the dumping site to the residential area divided by square of the distance from the residential area.

\section{Groundwater vulnerability (GW)}

Contamination of groundwater by a MSW dumping is the most highlighted and damaging environmental issue found in the literature (Demitriou et al. 2008, López et al. 2008, Singh et al. 2009, Li et al. 2012, Mahmood et al. 2013b). Leachate produced

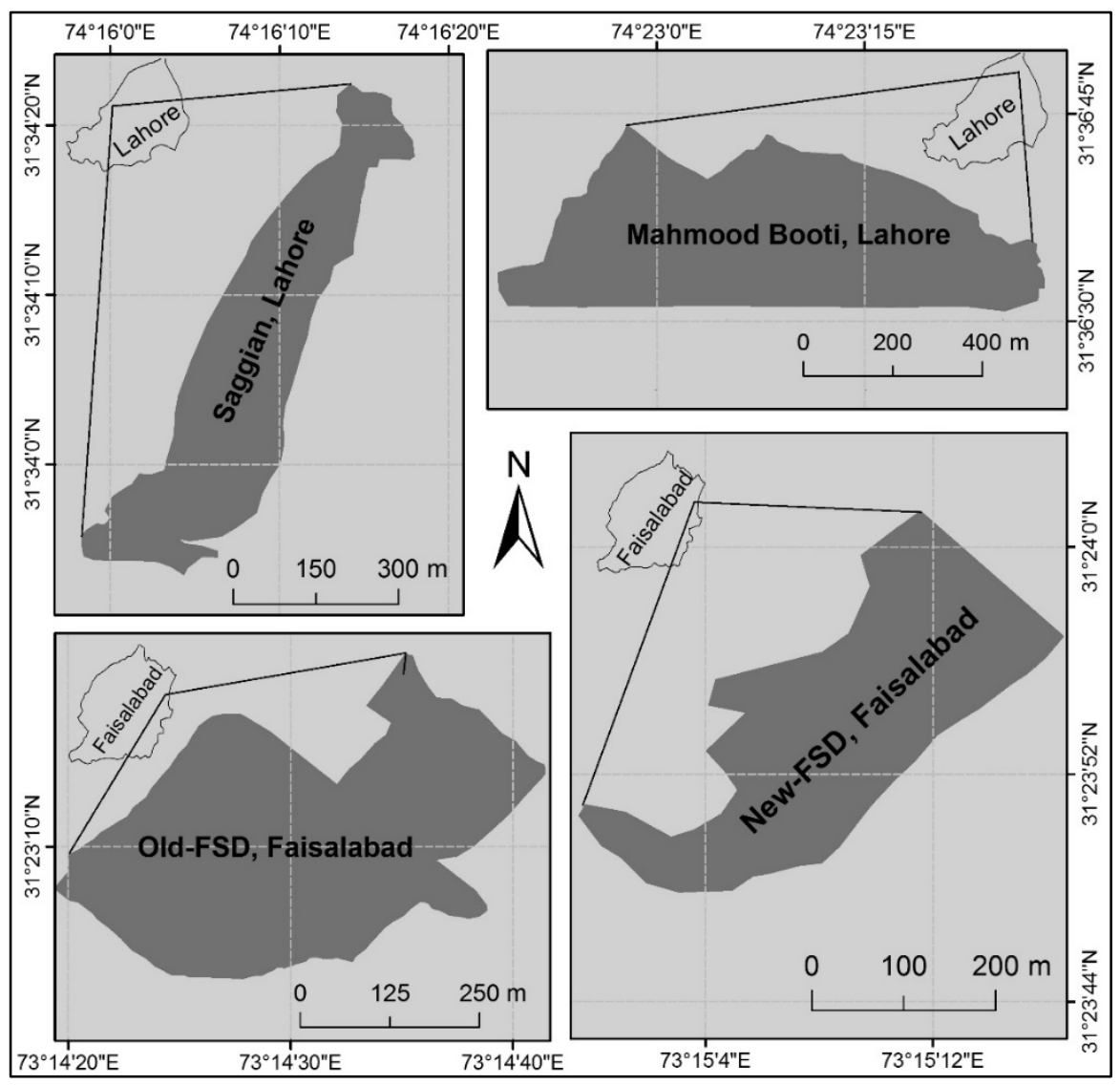

Fig. 1. Study area map 
in MSW percolates the underlying sediment/strata, mixes with water and contaminates it. Maximum contamination is expected in the downslope groundwater regions of the leachate producing source (Mahmood et al. 2013b). Groundwater risks have been categorized as: (GW1) depth of water table beneath dumping facility (the deeper the water table, the better the dumping site), (GW2) coefficient of permeability of underlying sediments (it must be as low as possible), (GW3) time taken by leachate to reach water table (it should be higher so that underlying lithology has enough time to reduce contamination of leachate), (GW4) amount of leachate production (the greater the amount, the worst are the conditions) and (GW5) angle between directions of the populated region and groundwater flow from dumping site (the maximum and the most suited value is $180^{\circ}$, whereas minimum and the least suited is $0^{\circ}$ ).

\section{Surface facilities (SF)}

It includes social facilities and surface water bodies in the form of river, streams or ponds. For the preservation of surface water resources from contamination, none of such facilities should exist near a MSW dump (Gbanie et al. 2013). The minimum distance suggested by Gbanie et al. 2013 is 150 meters, 100 meters by Babalola and Basu 2011 and 600 meters is suggested by Adeli and Khorshiddoust, 2011. A distance of $100 \mathrm{~m}$ to $800 \mathrm{~m}$ for different cases has been considered by Gorsevski et al. 2012 while 500 meter gap is considered by Sener et al. 2010. For this study, one of the parameters considered under this class is (SF1) area of a surface water body within $200 \mathrm{~m}$ of a MSW dump.

Social facilities included for analysis are roads, worship places and schools. Road infrastructure has been further divided into two parameters. At first place, the path to the dumping facility must be a proper concrete road that ensures access of MSW collection vehicles in all possible weather conditions. At second place, the existence of a highway or a frequently used road close to the MSW dump may cause road user to suffer in many ways. It enhances chances of accident due to animal activity around the site and a concentration diverting obnoxious smell in nearby atmosphere (Mahmood et al., 2015a). So the parameters taken are: (SF2) availability of concreate road access to dumping site, (SF3) length of a highway and frequently used road within $100 \mathrm{~m}$ of a dumping facility (this measurement should be zero as per international standards), (SF4) distance to closest worship place and (SF5) distance to closest school.

\section{Data collection and preparation}

Most of the input parameters have geography related measurements in and around dumping sites, therefore, GIS has been utilized in this study for preparing the input data. Land cover around the selected dumps has been prepared using remote sensing data of Quickbird with spatial resolution of $0.6 \mathrm{~m}$ ( $2.4 \mathrm{~m}$ multispectral merged with $0.6 \mathrm{~m}$ panchromatic). Unsupervised classification with Iterative Self Organizing DATa Analysis (ISODATA) algorithm has been conducted for classifying the satellite image into the land cover. The land cover is polygonised by the process of vectorization. Buffers for all the threshold distances were created and their overlay of intersection is performed with the land cover to figure out areas of various factors lying within the prohibited limits. Area of dumping sites is calculated using spatial analysis tool and height of the waste heap was measured by sites survey. Metrological data has been acquired from local meteorological departments, groundwater depth and vertical lithological log data from local Water and Sanitation Authorities (WASAs). The point data is interpolated using suitable techniques for each of the data sets in GIS environment. The downslope direction of groundwater beneath each of the site is mapped using technique of Inverted Watershed (Mahmood et al. 2013b). The house and population count is completed through ground survey of the buffer intersecting residential area.

\section{Algorithm}

Preparation of the input data of environmental variables leads to the need of some mathematical formulation that can make the comparison quantitative. For this study Fuzzy set theory has been utilized for standardizing all the variables over a common scale of 100 .

Scaling function is used to cope up with the uncertainty in the mutual controlling environment of selected input variables. As conceptualized, the base of the scaling function should be some comparative reference value. Therefore, first of all, the measured values for all selected sites, corresponding to each of the variables, have been accumulated to set the reference point.

$$
\mathrm{AHj}=\sum_{i=1}^{n} \mathrm{Hji}
$$

Where $\mathrm{AHj}$ is the accumulative reference value for the parameter $\mathrm{j}, \mathrm{n}$ is the number of dumps selected for the comparison, and $\mathrm{Hji}$ is the measured value of $\mathrm{j}^{\text {th }}$ parameter for $\mathrm{i}^{\text {th }}$ dump. The normalized score $(\mathrm{Sji})$ of $\mathrm{j}^{\text {th }}$ parameter for $\mathrm{i}^{\text {th }}$ dumpsite has been computed as below.

$$
\mathrm{Sji}=\frac{H j i}{\sum_{i=1}^{n} \mathrm{Hji}} \times 100
$$

The above formula works well only if the measurement of a variable contributes positively to environmental stability index (assigned highest normalized score to the site which is environmentally better under the parameter). But if a variable measurement behaves oppositely i.e. greater the residential area measurement within $1000 \mathrm{~m}$ buffer worst is the site, then the opposed variable should be inverted in the process of normalization and highest valued site must be ranked lowest. Therefore, normalization formula for an opposing variable is

$$
\begin{gathered}
\mathrm{Sji}=\left[\frac{S y-Y j i}{S y}+H j_{\min }\right] \times\left[10^{6} / \mathrm{Sy}\right] \\
\text { where } \mathrm{Yji}=H j_{\max }-\frac{H j i}{\sum_{i=1}^{n} \mathrm{Hji}} \\
\text { and } \mathrm{Sy}=\sum_{i=1}^{n} Y j i
\end{gathered}
$$

The conceptual diagram for onward methodology after normalization has been shown in Figure 2. 
Before combining the normalized scores from different parameters, a weight is necessary to be assigned to each of the individual parameters showing its relevant importance. Analytical Hierarchy process (AHP) developed by Saaty (Saaty 1997) has been used for the weight calculation. AHP has the advantage of reducing a multi-criteria problem into a pair-wise simple comparison for weighing the relative importance for each of the variables. Pairwise comparison has been first made within each class of five parameters for calculating individual class comparison as shown in Table 1. Then classes are mutually compared and assigned weight for the environmental stability index of the MSW dumps, shown in Table 2. Expert opinion has been used to quantify pairwise relation among the variables.

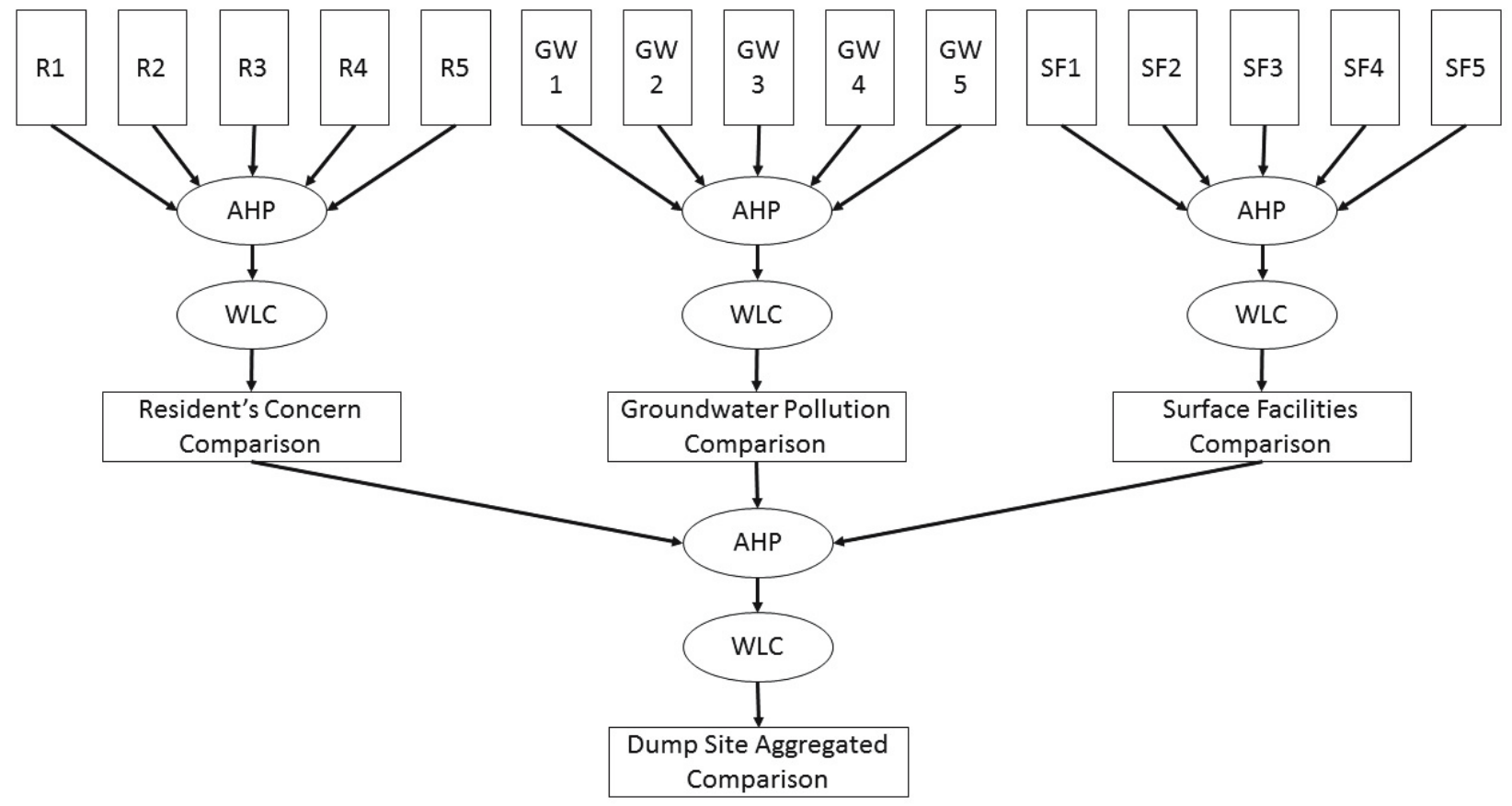

Fig. 2 Conceptual diagram of the ranking model

Table 1. Class wise pairwise comparison using AHP for calculating weights

\begin{tabular}{|c|c|c|c|c|c|c|c|c|c|}
\hline \multicolumn{10}{|c|}{ Residents' concerns } \\
\hline & R1 & $\mathrm{R} 2$ & R3 & $\mathrm{R} 4$ & R5 & Weights & Products & Ratio & $\mathrm{Cl} / \mathrm{RI}$ \\
\hline R1 & 1 & 3 & 2 & 1 & 2.5 & 0.317808 & 1.598921 & 5.031091 & 0.004 \\
\hline $\mathrm{R} 2$ & 0.33 & 1 & 1 & 0.5 & 1 & 0.129428 & 0.648391 & 5.009659 & \\
\hline R3 & 0.5 & 1 & 1 & 0.5 & 1 & 0.139737 & 0.701359 & 5.01912 & \\
\hline R4 & 1 & 2 & 2 & 1 & 2 & 0.279475 & 1.402717 & 5.01912 & \\
\hline R5 & 0.4 & 1 & 1 & 0.5 & 1 & 0.133552 & 0.669578 & 5.013619 & \\
\hline \multicolumn{10}{|c|}{ Groundwater Risks } \\
\hline & GW1 & GW2 & GW3 & GW4 & GW5 & Weights & Products & Ratio & $\mathrm{Cl} / \mathrm{RI}$ \\
\hline GW1 & 1 & 0.67 & 2 & 1.5 & 1.5 & 0.218972 & 1.38146 & 5.285266 & 0.01 \\
\hline GW2 & 1.5 & 1 & 3 & 3 & 2.5 & 0.369948 & 2.227469 & 5.044167 & \\
\hline GW3 & 0.5 & 0.33 & 1 & 1.33 & 1.33 & 0.150209 & 0.871337 & 4.859679 & \\
\hline GW4 & 0.67 & 0.33 & 0.75 & 1 & 1 & 0.129737 & 0.767653 & 4.957007 & \\
\hline GW5 & 0.67 & 0.4 & 0.75 & 1 & 1 & 0.131133 & 0.797093 & 5.092304 & \\
\hline \multicolumn{10}{|c|}{ Surface Facilities } \\
\hline & SF1 & SF2 & SF3 & SF4 & SF5 & Weights & Products & Ratio & $\mathrm{Cl} / \mathrm{RI}$ \\
\hline SF1 & 1 & 4 & 2 & 1 & 1 & 0.278949 & 1.46404 & 4.834879 & -0.021 \\
\hline SF2 & 0.25 & 1 & 0.5 & 0.25 & 0.25 & 0.069737 & 0.36601 & 4.834879 & \\
\hline SF3 & 0.5 & 2 & 1 & 0.5 & 0.5 & 0.139475 & 0.73202 & 4.834879 & \\
\hline SF4 & 1 & 4 & 2 & 1 & 1 & 0.278949 & 1.46404 & 4.834879 & \\
\hline SF5 & 1 & 2 & 2 & 1 & 1 & 0.232889 & 1.312636 & 5.192225 & \\
\hline
\end{tabular}


The final comparative score for all three classes and then their combined result for every individual dump was computed using weighted linear combination (WLC) by the following equation.

$$
\mathrm{Fi}=\sum_{j=1}^{m} \mathrm{Wj} \times \mathrm{Sji}
$$

Where $\mathrm{Wj}$ is the weight of the $\mathrm{j}^{\text {th }}$ parameter in the class score calculations and in the environmental suitability index it will present weight of a class.

\section{Results and discussion}

Environment friendly MSW disposal facilities are highly needed and the objective can only be achieved with proper engineering of the landfill. Here, in this study, the focus was to rank the sites over some quantitative scale that can aid local authorities in decision of prioritizing the budget as well as resources allocation for taking control measures against open dumps. A set of four open dumps have been taken to explain the working of the algorithm. The comparison has been made at two levels, i.e., class level and aggregated level. The results obtained from class level comparison have been shown in Table 3.

\section{Resident's concerns}

In 1987, MSW waste was shipped from New York to North Carolina, where it was planned to be used for the production of energy. The shipment was refused by the expected destiny, from where it went on to Louisiana, Mississippi, Florida, Mexico, Belize and Texas, but all the ports refused it and so the garbage returned back to New York (for details Pasternack 2013). It leads to the conclusion that nobody wants garbage in its backyard and this political and aesthetic repulsion has formed basis of the Resident's concern about location of the waste disposal facility. The quantitative comparison of all four dumps has been given in Table 3A.

Table 2. Pairwise class comparison for Environmental ranking weights

\begin{tabular}{|l|c|c|c|c|c|c|c|}
\hline & R & GW & SF & Weights & Products & Ratio & Cl/RI \\
\hline R & 1 & 0.67 & 2 & $\mathbf{0 . 3 2 2 2 9 1}$ & 0.969634 & 3.008565 & 0.007 \\
\hline GW & 1.5 & 1 & 4 & $\mathbf{0 . 5 3 1 0 5 6}$ & 1.601104 & 3.014945 & \\
\hline SF & 0.5 & 0.25 & 1 & $\mathbf{0 . 1 4 6 6 5 3}$ & 0.440562 & 3.004118 & \\
\hline
\end{tabular}

Table 3. Approximated Normalized Scores and Comparative WLC Ranking

\begin{tabular}{|c|c|c|c|c|c|c|}
\hline \multicolumn{7}{|c|}{ (A) Resident's Concern Comparison } \\
\hline Parameters & $\begin{array}{c}\mathrm{R} 1 \\
\text { (Standardized) }\end{array}$ & $\begin{array}{c}\mathrm{R} 2 \\
\text { (Standardized) }\end{array}$ & $\begin{array}{c}\mathrm{R} 3 \\
\text { (Standardized) }\end{array}$ & $\begin{array}{c}\mathrm{R} 4 \\
\text { (Standardized) }\end{array}$ & $\begin{array}{c}\text { R5 } \\
\text { (Standardized) }\end{array}$ & WLC \\
\hline Weights & 0.317808 & 0.129428 & 0.139737 & 0.279475 & 0.133552 & \\
\hline Saggian & 0.953289 & 11.245023 & 13.433606 & 13.6654392 & 0.21995 & 7.484079 \\
\hline Mahmood Booti & 20.01907 & 0.5448456 & 1.0202317 & 1.38945193 & 34.05069 & 11.51116 \\
\hline Old FSD & 2.57388 & 41.667178 & 42.921556 & 42.5189286 & 31.60048 & 28.31191 \\
\hline New FSD & 76.45377 & 46.542953 & 42.6246067 & 42.42618031 & 34.12888 & 52.69285 \\
\hline \multicolumn{7}{|c|}{ (B) Groundwater Vulnerability Comparison } \\
\hline Parameters & $\begin{array}{c}\text { GW1 } \\
\text { (Standardized) }\end{array}$ & $\begin{array}{c}\mathrm{R} 2 \\
\text { (Standardized) }\end{array}$ & $\begin{array}{c}\mathrm{R} 3 \\
\text { (Standardized) }\end{array}$ & $\begin{array}{c}\mathrm{R} 4 \\
\text { (Standardized) }\end{array}$ & $\begin{array}{c}\text { R5 } \\
\text { (Standardized) }\end{array}$ & WLC \\
\hline Weights & 0.218972 & 0.3699481 & 0.1502092 & 0.12973689 & 0.131133 & \\
\hline Saggian & 29.20326 & 8.9206066 & 11.591479 & 26.1641199 & 0 & 14.83047 \\
\hline Mahmood Booti & 41.84895 & 28.15953 & 44.611529 & 10.9067189 & 0 & 27.6974 \\
\hline Old FSD & 13.69951 & 31.459932 & 20.739348 & 28.4569761 & 48.14815 & 27.75935 \\
\hline New FSD & 15.24828 & 31.459932 & 23.057644 & 34.4721852 & 51.85185 & 29.71279 \\
\hline \multicolumn{7}{|c|}{ (C) Surface Facilities Comparison } \\
\hline Parameters & $\begin{array}{c}\text { SF1 } \\
\text { (Standardized) }\end{array}$ & $\begin{array}{c}\mathrm{R} 2 \\
\text { (Standardized) }\end{array}$ & $\begin{array}{c}\mathrm{R} 3 \\
\text { (Standardized) }\end{array}$ & $\begin{array}{c}\mathrm{R} 4 \\
\text { (Standardized) }\end{array}$ & $\begin{array}{c}\mathrm{R} 5 \\
\text { (Standardized) }\end{array}$ & WLC \\
\hline Weights & 0.278949 & 0.0697374 & 0.1394747 & 0.27894945 & 0.232889 & \\
\hline Saggian & 0 & 0 & 33.333333 & 44.50827982 & 24.7474747 & 22.82813 \\
\hline Mahmood Booti & 33.33333 & 33.333333 & 0 & 18.41838459 & 11.2706007 & 19.38549 \\
\hline Old FSD & 33.33333 & 33.333333 & 33.333333 & 12.30145319 & 48.989899 & 31.11274 \\
\hline New FSD & 33.33333 & 33.333333 & 33.333333 & 24.77188239 & 14.9920255 & 26.67363 \\
\hline
\end{tabular}


Highest weight has been assigned to the distance of residential area from dumping site (R1) and population living in a kilometer of dumps (R4), as they are the main standard criteria as found in the reviewed literature (Eiselt and Marianov 2015, Mahmood et al. 2015a). Residential area within 1,000 m (R2) and number of houses within 1,000 m (R3) are taken as sub standards or the supporting criteria. The comparison has highlighted new dump of Faisalabad (New-FSD) as a top site in addressing concerns of residents and worst is the Saggian dump. Distance from residential area (R1) is the most prominent contributor in selecting the leading and trailing sites, as shown in Figure 3. Distance of New-FSD from residential area is $802 \mathrm{~m}$ that has made it best among the others, whereas the Saggian dump is just adjacent to a human colony. Response of both the Faisalabad sites to R3 and R4 is almost similar whereas in the case of R5 Mahmood Booti has also joined the leading sites. As the quantitative comparison has assigned a comparative scale of hazardous impacts, so compared to the worst site of Saggian, Mahmood Booti is about 1.5 times better, similarly Old-FSD and New-FSD are 3.8 and 7 times better respectively. The hierarchy of goodness for Resident's Concerns is as New-FSD > Old-FSD > Mahmood Booti > Saggian. Considering highest ranked New-FSD as the perfect; Old-FSD lies at 53\%, Mahmood Booti at 21.8\% and Saggian at $14.2 \%$.

This evaluation is based on the current situation but in the future Old-FSD may be ranked worst, as a new housing society has been planned at about $100 \mathrm{~m}$ distance from it. If its development could not be stopped then all the main and supporting parameters will decrease to such level that local government may have to remove that dump, same as it is immediately needed for the Saggian dump.

\section{Groundwater vulnerability}

Approximately 99\% liquid fresh water of the world is in underground aquifers (ESA 2001) and at least a quarter of the world's population draws its water from this source (King and Clarke 2004, Mahmood et al. 2013a). Groundwater contamination by leachate from the dumping sites is the most highlighted and damaging environmental issue (Butt and Oduyemi 2008, Santos et al. 2006, Demitriou 2008, López et al. 2008, Singh et al. 2009, Li et al. 2012, Butt and Ghafar 2012, Akhtar and Tang 2014). Groundwater quality near the Mahmood Booti dump has already been reported unfit for drinking as per WHO standards (Butt and Ghaffar 2012, Mahmood et al. 2013b, Akhtar and Tang 2014). The supply of drinking water in Lahore is completely met by extracted groundwater. The situation is different in main city of Faisalabad, where abstracting local groundwater is not the source to fulfill domestic needs. However, villages around both the old and new dumps are abstracting the local groundwater for drinking and other domestic uses. So, ultimately groundwater protection level around all four dumps is an equally important environmental consideration.

Groundwater vulnerability to MSW leachate has been compared in Figure 4. Groundwater depth beneath dumping site (GW1) and co-efficient of permeability (GW2) have been taken as main standards and are given higher weights. For the preservation of groundwater quality, New-FSD has been ranked best but the level is not higher than others as was in the case for resident's concerns. New-FSD has shown its supremacy for GW4 and GW5. Whereas, better areas of Mahmood Booti are GW1 and GW3, but GW4 and GW5 have really made it adverse for groundwater protection. Mahmood Booti and Old-FSD are almost ranked equal and their level of groundwater protection is a bit lower than that of the top MSW facility of New-FSD. The rate of groundwater abstraction is high in the city of Lahore and a cone like depression has been developed that has affected the vulnerability in two ways (Mahmood et al. 2013a). At first the water table has been dropped down to the depths of more than $40 \mathrm{~m}$, causing higher score of GW1 for both Saggian and Mahmood Booti dumps. Secondly, as both the dumps are located at outskirts of the city, the effect of leachate always moves towards the center of the city, due to the depression slope, making standardized values of GW5 zero.

Being not the main source for domestic and agriculture usage groundwater is higher in Faisalabad. The natural lithological barrier for the prevention of underlying aquifer from leachate is better in Faisalabad than Lahore due to the existence of clay beds making higher scores of GW2 for both

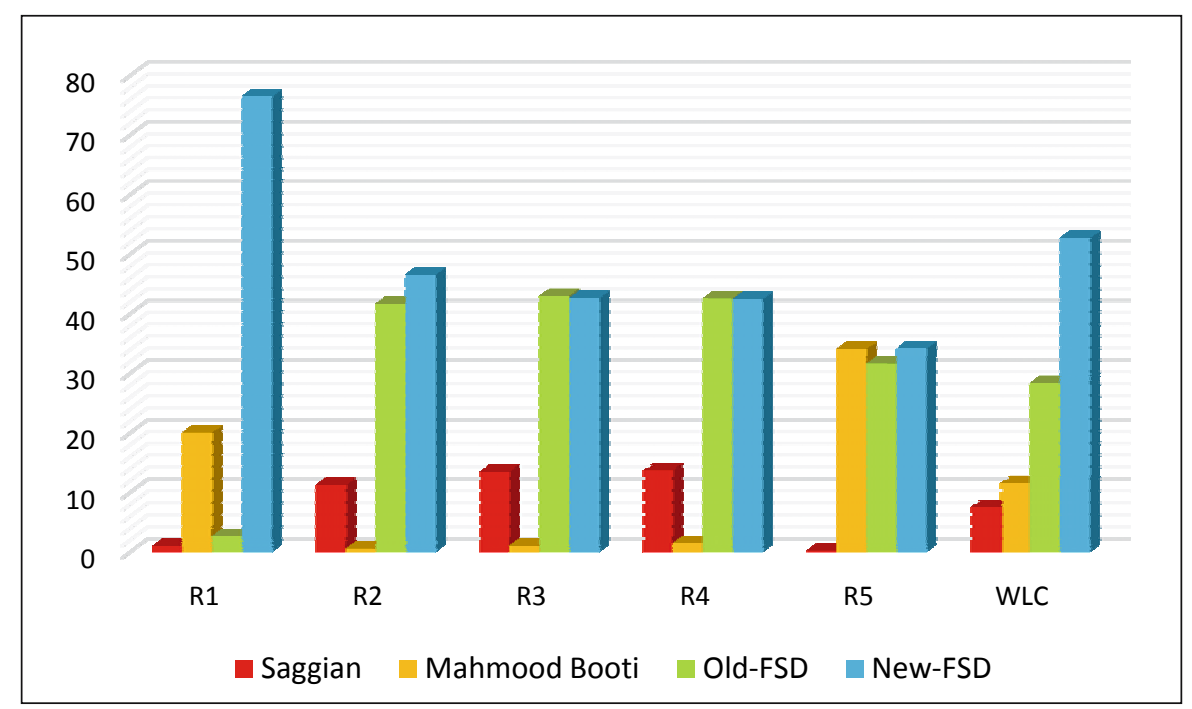

Fig. 3. Resident's Concerns Comparison 
new and old dumps here. Production of leachate at piles of MSW is obvious but there are many preventive measures that may be available only for a proper engineered landfill like leachate collection system. It is important here that none of the studied sides is a proper landfill and they are just open dumps. Faisalabad government has proposed the New-FSD and its surrounding area for the construction of proper landfill. Whenever it happens, it will make it even better MSW dumping facility. The hierarchy of goodness for groundwater prevention is the same as for the Resident's Concerns but the difference in the levels of goodness is not that much higher, as compared to highest ranked New-FSD, Old-FSD lies at 93.4\%, Mahmood Booti at $93.2 \%$ and Saggian at $49.9 \%$.

\section{Surface facilities}

A sufficient distance between MSW dumping site and surface water resources is essential to minimize the potential hazards associated with leachate (Gbanie et al. 2013). Similarly, any public facility or community center must be constructed as away from dumps as possible. In actual a dumping site should be chosen away from these facilities but this study is focusing on the practices of developing world, where the sites have already been opted without considering any of the environmental or esthetic rules.

The only water body which exists in the study area is the river Ravi that passes adjacent to Saggian dump. None of the other sites has any surface water body within the specified $200 \mathrm{~m}$ buffer.

The settlements around Saggian and Old-FSD are illegal and therefore no school exists in their immediate vicinity causing their SF5 scores higher. There should not exist any highway or frequently used road in $100 \mathrm{~m}$ of a dumping facility. Among all four sites a highway exists in the threshold zone of Mahmood Booti therefor all the remaining three are assigned highest and equal score. Only Saggian is the site that does not have a proper road approach so that waste carrying vehicles could easily reach there in all seasons and does not unload their carriage on the way due to any kind of seasonal disturbance to the path. Site comparison for Surface Facilities is given in Table $3 \mathrm{C}$.

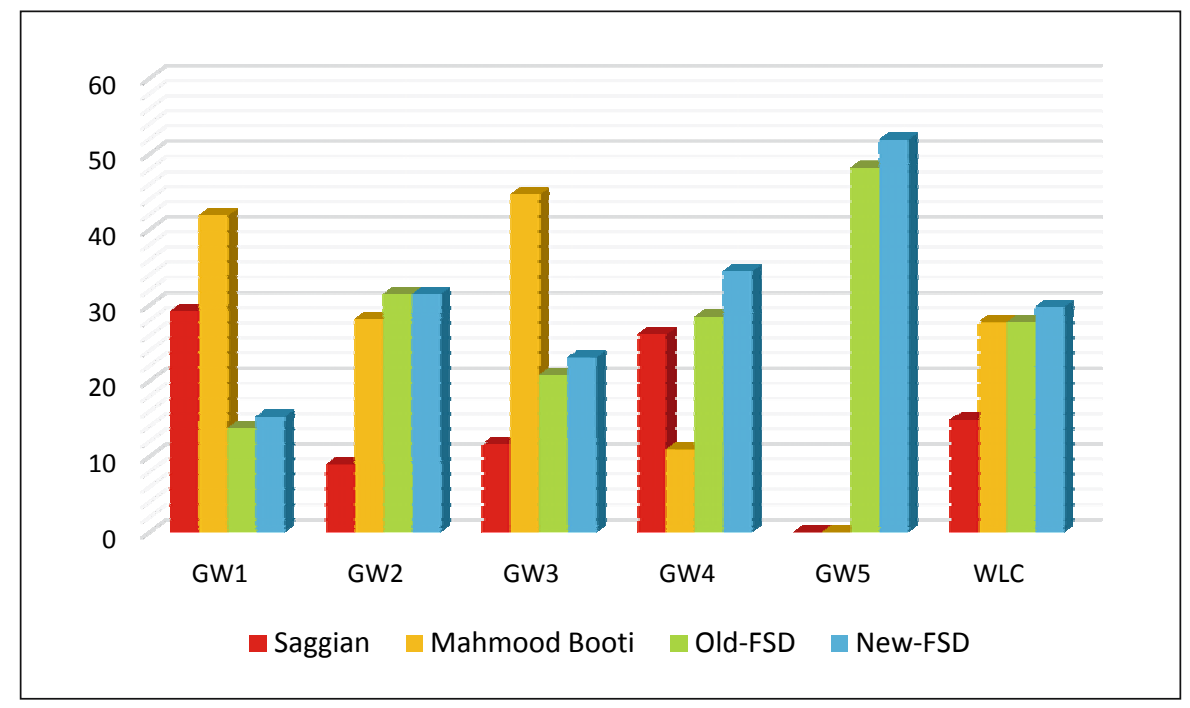

Fig. 4. Comparison of the Groundwater Vulnerability

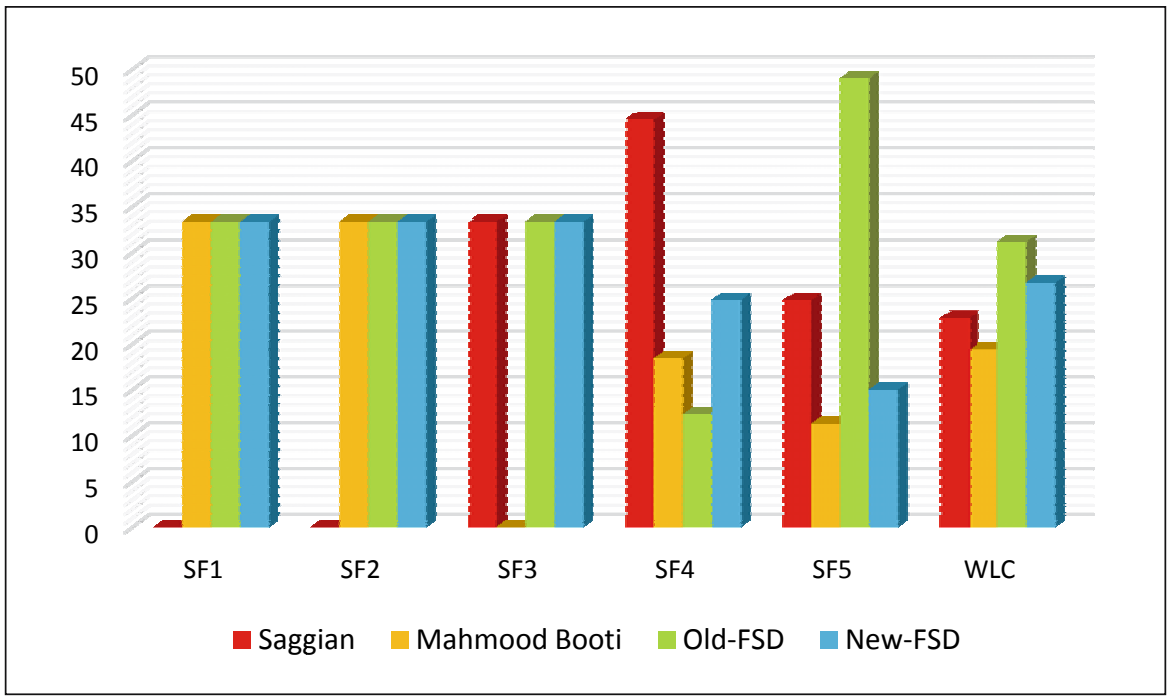

Fig. 5. Comparison of Hazardous Impacts to Surface Facilities 
Hazards ranking, based on surface facility has ranked Old-FSD at highest place, whereas worst in this case is the Mahmood Booti, government owned dumping site for Lahore. The major difference is caused by the factor FS5 (distance to closest school), shown in Figure 5. Although SF4 and SF5 scores of Saggian are good as compared to other sites, SF1 and SF2 have done real damage to its suitability regarding preservation of Surface Facilities. The expansion in the city of Lahore has made its dumps closer to every social facility; whereas, dumps of Faisalabad are far away from the main city and their toxic effect is confined to nearby villages. The hierarchy of goodness for this category is somehow different and is as Old-FSD $>$ New-FSD $>$ Saggian $>$ Mahmood Booti. Considering highest ranked Old-FSD as 100\%, New-FSD lies at $85.7 \%$, Mahmood Booti at $62.3 \%$ and Saggian at $73.4 \%$.

\section{Environmental suitability index}

The hierarchy of AHP and WLC over class scores has made it possible to generate a quantitative comparison of all the sites and the results are shown in Table 4. Groundwater is assigned highest weight as its pollution is almost irreversible process (Saidi et al. 2011, Wang et al. 2012). Even with the advances in technology, rehabilitation of polluted groundwater is very difficult and heavy investment is needed for a long period of time, which is not practical, especially in developing countries (Hailin et al. 2011, Majandang 2013, Mahmood et al. 2015b).

The algorithm has successfully ranked the all four sites with the results that New-FSD is better than all the others in securing the environment, as shown in Figure 6. The prominent factors that have marked suitability of the leading New-FSD, are R1, R2 and GW5. Good controlled factors of Old-FSD are R2, R3, R4 and GW5, and strong environmental protection areas for the third ranked, Mahmood Booti, are R5, GW1, SF1 and SF2. Although the highest weight has been assigned to groundwater vulnerability, the leading edge of New-FSD is its higher scores in addressing Resident's concerns. Saggian is the worst MSW dumping facility and is almost equally detrimental to all three classes of environmental concern, with the exception found for the parameter SF4. Although Saggian has already been forbidden for MSW dumping, the old deposits are damaging the environment and need immediately to be cleaned. Mahmood Booti being better than Saggian has officially been chosen as the dumping facility but alone it is unable to bear the load of a mega city. The location of New-FSD has already been chosen for the construction of a landfill which is good for the environmental stability of the area.

Table 4. Environmental Impact Comparison

\begin{tabular}{|l|c|c|c|c|}
\hline \multicolumn{1}{|c|}{ Parameters } & $\begin{array}{c}\text { Resident's Concerns } \\
\text { (R) }\end{array}$ & $\begin{array}{c}\text { Groundwater } \\
\text { (GW) }\end{array}$ & $\begin{array}{c}\text { Surface Facilities } \\
\text { (SF) }\end{array}$ & WLC \\
\hline Weights & $\mathbf{0 . 3 2 2 2 9 1}$ & $\mathbf{0 . 5 3 1 0 5 6}$ & $\mathbf{0 . 1 4 6 6 5 3}$ & \\
\hline Saggian & 7.48407876 & 14.8304663 & 22.8281326 & 13.63567347 \\
\hline Mahmood Booti & 11.5111566 & 27.6973951 & 19.3854912 & 21.2617505 \\
\hline Old FSD & 28.3119138 & 27.7593478 & 31.1127438 & 28.42922044 \\
\hline New FSD & 52.6928508 & 29.7127908 & 26.6736324 & 36.67335559 \\
\hline
\end{tabular}

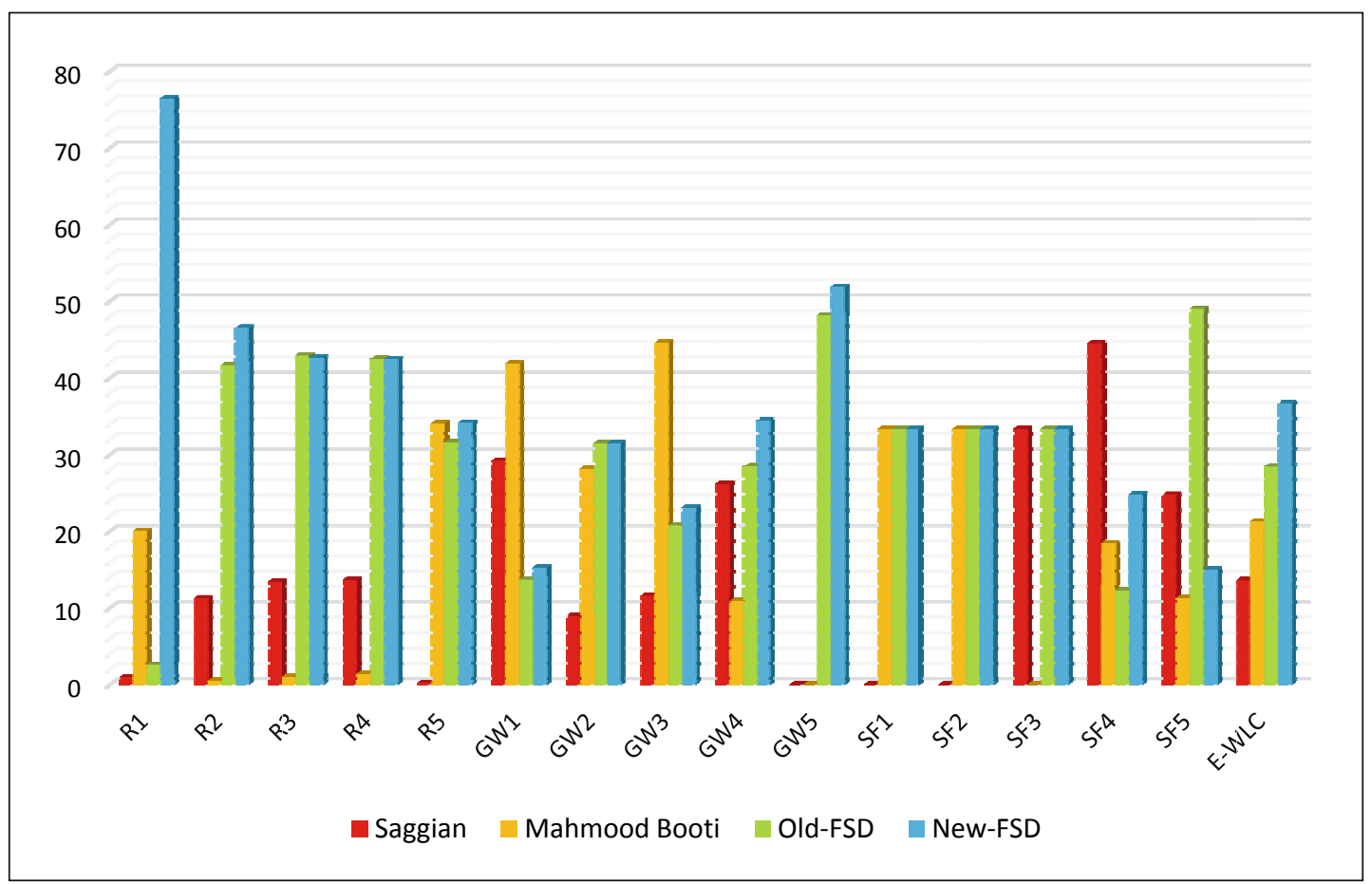

Fig. 6. Overall Environmental Suitability Comparison 


\section{Conclusion}

It is essential to prioritize do's, especially when we have limited resources. A mathematical prioritization scheme for existing non-engineered MSW dumps has been proposed and successfully implemented in this study. Study scheme is very flexible to incorporate any number of classes and any number of parameters in a class. This flexibility is highly needed for developing world where availability of data is the biggest hurdle in research based planning for environmental sustainability. The proposed model can be run even without a professional level understanding of the GIS software and acquiring expensive satellite data, with little inaccuracy, using imagery and measurement tools provided by Google Earth.

Four existing dumps have been compared to explain working and implementation of the developed ranking algorithm, named Saggian, Mahmood Booti, Old-FSD and New-FSD. To get a better insight in to the situation testing parameters were divided into three classes: Resident's Concerns, Groundwater Vulnerability and Surfaces Facilities. All the considered dumps are potentially hazardous to residents living in their neighboring regions. However, Resident's concerns have been better address by New-FSD with a comparative score of 52.7, whereas Saggian has been ranked lowest (7.5), as it shares its boundaries with a residential colony. Vulnerability of groundwater to the mixing of leachate is found highest for Saggian which has been ranked very low on comparative scale of groundwater prevention, i.e. 14.8, whereas the highest score of 29.7 belongs to New-FSD. Leading and the trailing scenario has been entirely changed for Surface Facilities protection and the highest score is 31 that belongs to Old-FSD and the lowest is 19.4 , belonging to Mahmood Booti. A length of $1,165 \mathrm{~m}$ of a three lane Ring road of Lahore with 38,620 vehicles per day falls within 100 meters of Mahmood Booti dump. The frequency of road accidents found over this patch of Ring road is higher as compared to its surroundings (Mahmood et al. 2015a).

As per Environmental Suitability Index, showing overall environmental protection status, the found hierarchy of goodness is as New-FSD > Old-FSD > Mahmood Booti > Saggian, having scores 36.7, 28.4, 21.3 and 13.6 respectively. Mahmood Booti is still ranked better than Saggian because in overall comparison the lowest weight has been given to surface facilities and highest to groundwater vulnerability. If compared with the best score for New-FSD (i.e. 36.7), Old-FSD falls at its $77 \%$, Mahmood Booti at 58\% and Saggian at 37\%.

\section{References}

Adeli, Z. \& Khorshiddoust, A. (2011). Application of geomorphology in urban planning: Case study in landfill site selection, Procedia Social and Behavioral Sciences, 19, pp. 662-667.

Akhtar, M.M. \& Tang, Z. (2014). Municipal solid waste and its relation with groundwater contamination in Lahore, Pakistan, Research Journal of Applied Sciences, Engineering and Technology, 7(8), pp. 1551-1560.

Alam, K., Trautmann, T., Blaschke, T. \& Majid, H. (2012). Aerosol optical and radiative properties during summer and winter seasons over Lahore and Karachi, Atmospheric Environment, 50, pp. 234-245.

Ali, S.M., Pervaiz, A., Afzal, B. \& Hamid, N. (2014). Open dumping of municipal solid waste and its hazardous impacts on soil and vegetation diversity at waste dumping sites of Islamabad city, Journal of King Saud University - Science, 26, pp. 59-65.

Al-jarrah, O. \& Abu-Qdais, H. (2006). Municipal solid waste landfill siting using intelligent system, Waste Management, 26, pp. 229-206.

Babalola, A. \& Basu, I. (2011). Selection of landfill sites for solid waste treatment in Damaturu Town-Using GIS techniques, Journal of Environmental Protection, 2, pp. 1-10.

Biswas, A.K., Kumar, S., Babu, S., Bhattaacharyya, J.K. \& Chakrabarti, T. (2010). Studies of environmental quality in and around municipal solid waste dumpsite, Resources, Conservation and Recycling, 55(2), pp. 129-134.

Butt, I. \& Ghaffar, A. (2012). Ground water quality assessment near Mehmood Boti landfill, Lahore, Pakistan, Asian Journal of Social Sciences \& Humanities, 1(2), pp. 13-24.

Butt, T.E., Lockley, E. \& Oduyemi, K.O.K. (2008). Risk assessment of landfill disposal sites - State of the art, Waste Management, 28, pp. 952-964.

Demitriou, E., Karaozas, I., Saratakos, K., Zacharias, I., Bogdanos, K. \& Diapoulis, A. (2008). Groundwater risk assessment at a heavily industrialized catchment and the associated impacts on a peri-urban wetland, Journal of Environmental Management, 988, pp. 526-538.

District Census Report of Lahore (2000). Issued by population census organization statistics division government of Pakistan, Islamabad, Pakistan 2000.

Eiselt, H.A. \& Marianov, V. (2015). Location modeling for municipal solid waste facilities, Computer \& Operation Research, 62, pp. 305-315.

ESA (2001). Water in a changing world, Journal of Issues in Ecology, Ecological Society of America, Vol. 9.

Gbani, S.P., Tengbe, P.B., Momoh, J.S., Medo, J. \& Kabba, V.T.S. (2013). Modeling landfill location using Geographic Information Systems (GIS) and Multi-Criteria Decision Analysis (MCDA): Acase study Bo, Southern Sierra Leone, Applied Geography, 36, pp. 3-12.

Gorsevski, P.V., Donevska, K.R., Mitrovski, C.D. \& Frizado, J.P. (2012). Integrating multi-criteria evaluation techniques with geographic information systems for landfill site selection: A case study using ordered weighted average, Waste Management, 32, pp. 287-296.

Hailin, Y., Ligang, X., Chang, Y. \& Jiaxing, X. (2011). Evaluation of groundwater vulnerability with improved DRASTIC Method, Procedia Environmental Sciences, 10, pp. 2690-2695.

Hazra, T. \& Goel, S. (2009). Solid waste management in Kolkata, India: practices and challenges, Waste Management, 29, pp. 470-478.

Jiang, H. \& Eastman, R.J. (2000). Application of fuzzy measures in multi-criteria evaluation in GIS, International Journal of Geographical Information Systems, 14, pp. 173-184.

King, J. \& Clarke, R. (2004). The water atlas a unique visual analysis of the world's most critical resource, spring, ISBN: 978-1-56584-907-5.

Li, Y., Li, J., Chen, S. \& Diao, W. (2012). Establishing indices for groundwater contamination risk assessment in the vicinity of hazardous waste landfills in China, Environmental Pollution, 165, pp. 77-90.

Liu, H.C., You, J.X., Fan, X.J. \& Chen, Y.Z. (2014). Site selection in waste management by VIKOR method using linguistic assessment, Applied Soft Computing, 21, pp. 453-461.

López, J.A.R., Hernández, J.R., Mancilla, O.L., Diazconti, C.C. \& Garrido, M.L. (2008). Assessment of groundwater contamination by landfill leachate: A case in México, Waste Management, 28, pp. 33-39.

Mahini, S.A. \& Gholamafard, M. (2006). Siting MSW landfills with a weighted linear combination methodology in a GIS Environment, International Journal of Environmental Science Technology, 3(4), pp. 435-445. 
Mahmood, K., Batool, S.A., Chaudhary, M.N. \& Daud, A. (2015a). Evaluating muncipal solid waste dumps using Geographic Information System, Polish Journal of Environmental Studies, 24 (2), pp. 879-886.

Mahmood, K., Batool, S.A., Rana, A.D., Tariq, S., Ali, Z. \& Chaudhry, M.N. (2013b). Assessment of leachate effects to the drinking water supply units in the down slope regions of municipal solid waste (MSW) dumping sites in Lahore Pakistan, International Journal of Physical Sciences, 8(28), pp. 1470-1480.

Mahmood, K., Daud, A., Tariq, S., Kanwal, S., Ali, R., Haider, A. \& Tahseen, T. (2013a). Groundwater levels susceptibility to degradation in Lahore metropolitan, Science International (Lahore), 25(1), pp. 123-126.

Mahmood, K., Khan, R.M., Ashfaq, M., Ahsan, H., Shakoor, Z. \& Tanveer, M. (2015b). Assessment of the intrinsic vulnerability to groundwater contamination in Lahore, Pakistan, Pakistan Journal of Scientific and Industrial Research, 58(1), pp. 8-16.

Majandang, J. \& Sarapirome, S. (2013). Groundwater vulnerability assessment and sensitivity analysis in NongRua, KhonKaen, Thailand using a GIS-based SINTACS Model, Environmental Earth Sciences, 68, pp. 2025-2039.

Marzougui, A. \& Mammou, A.B. (2006). Impacts of dumping site on the environment: case of the Henchir El Yahoudia Site, Tunis, Tunsia, Comptes Rendus Geoscience, 338, pp. 1176-1183.

Pasternack, A. (2013). The most watched load of garbage in the memory of man, (http://motherboard.vice.com/blog/themobro-4000(03.06.2015).

Rahman, A. (2008). A GIS based DRASTIC model for assessing groundwater vulnerability in shallow aquifer in Aligarh, India, Applied Geography, 28, pp. 32-53.

Saaty, T.L. (1997). The analytical network process, RWS Publications, 4922 Ellsworth Avenue, Pittsburgh, PA 15213.
Saidi, S., Bouri, S., Dhia, B. \& Anselme, B. (2011). Assessment of groundwater risk using intrinsic vulnerability mapping: application to Souassi Aquifer, Tunisian Sahel, Agricultural Water Management, 98, pp. 1671-1682.

Santos, F.A.M., Mateus, A., Figueiras, J. \& Gonçalves, M.A. (2006). Mapping groundwater contamination around a landfill facility using the VLF-EM method - A case study, Journal of Applied Geophysics, 60, pp. 115-125.

Şener, S., Şener, E., Nas, B. \& Karagüzel, R. (2010). Combining AHP with GIS for landfill site selection: A case study in the Lake Beysehir catchment area (Konya, Turkey), Waste Management, 30, pp. 2037-2046.

Singh, R.K., Datta, M. \& Nema, A.K. (2009). A new system for groundwater contamination hazard rating of landfills, Journal of Environmental Management, 91, pp. 344-357.

Sumathi, V.R., Natesan, U. \& Sarkar, C. (2008). GIS-based approach for optimizing siting of municipal solid waste landfill, Waste Management, 28 (11), pp. 2146-2160.

Wang, J., He, J. \& Chen, H. (2012). Assessment of groundwater contamination risk using hazard quantification, a modified DRASTIC model and groundwater value, Beijing Plain, China, Science of the Total Environment, 432, pp. 216-226.

Zadeh, L.A. (1965). Fuzzy sets, Information and Control, 8, pp. 338-353.

Zadeh, L.A. (1978). Fuzzy sets as a basis for a theory of possibility, Fuzzy Sets and Systems, 1, pp. 3-28.

Zeinhom, E.A., Elhadary, R. \& Elashry, A. (2010). Integrating GIS and MCDM to deal with landfill site selection, International Journal of Engineering \& Technology, 10, pp. 32-42.

Zhang, H., Zhang, D.Q., Jin, T.F., He, P.J., Shao, Z.H. \& Shao, L.M. (2011). Environmental and economic assessment of combined biostabilization and landfill for municipal solid waste, Journal of Environmental Management, 92, pp. 2533-2538. 